\title{
Napthrene Compounds from Mycelial Fermentation Products of Marasmius berteroi
}

\author{
Ning Ning Yang ${ }^{1,2, \dagger}$, Qing Yun Ma 1,3,†, Fan Dong Kong ${ }^{1,3}$, Qing Yi Xie 1,3, Hao Fu Dai 1,3, \\ Li Man Zhou ${ }^{1}$, Zhi Fang Yu ${ }^{4, *}$ and You Xing Zhao ${ }^{1,3, *}$ \\ 1 Hainan Key Laboratory for Research and Development of Natural Product from Li Folk Medicine, Institute \\ of Tropical Bioscience and Biotechnology, Chinese Academy of Tropical Agricultural Sciences, \\ Haikou 571101, China; yangningning891216@163.com (N.N.Y.); maqingyun@itbb.org.cn (Q.Y.M.); \\ kongfandong@itbb.org.cn (F.D.K.); xieqingyi@itbb.org.cn (Q.Y.X.); daihaofu@itbb.org.cn (H.F.D.); \\ zhouliman88@163.com (L.M.Z.) \\ 2 College of Food and Bioengineering, Bengbu University, Bengbu 233030, China \\ 3 Hainan Institute for Tropical Agricultural Resources, Chinese Academy of Tropical Agricultural Sciences, \\ Haikou 571101, China \\ 4 College of Food Science and Technology, Nanjing Agricultural University, Nanjing 210095, China \\ * Correspondence: yuzhifang@njau.edu.cn (Z.F.Y.); zhaoyouxing@itbb.org.cn (Y.X.Z.) \\ + These authors contributed equally to this work.
}

Received: 15 July 2020; Accepted: 24 August 2020; Published: 26 August 2020

\begin{abstract}
The metabolites of the genus Marasmius are diverse, showing good research prospects for finding new bioactive molecules. In order to explore the active metabolites of the fungi Marasmius berteroi, the deep chemical investigation on the bioactive compounds from its cultures was undertaken, which led to the isolation of three new naphthalene compounds dipolynaphthalenes A-B $(\mathbf{1 , 2})$ and naphthone $C$ (3), as well as 12 known compounds (4-15). Compounds 1, 2, and 4 are dimeric naphthalene compounds. Their structures were elucidated by MS, 1D and 2D NMR spectroscopic data, as well as ECD calculations. Compounds $\mathbf{2} \mathbf{- 4}$ and $\mathbf{7}$ exhibited acetylcholinesterase (AChE) inhibitory activities at the concentration of $50 \mu \mathrm{g} / \mathrm{mL}$ with inhibition ratios of $42.74 \%, 44.63 \%, 39.50 \%$ and $51.49 \%$, respectively. Compounds 5, 7 and 8 showed weak inhibitory activities towards two tumor cell lines, with $\mathrm{IC}_{50}$ of $0.10,0.076$ and $0.058 \mathrm{mM}$ (K562) and $0.13,0.18$, and $0.15 \mathrm{mM}$ (SGC-7901), respectively.
\end{abstract}

Keywords: Marasmius berteroi; dipolynaphthalenes; binapthrene; AChE inhibitory activity; cytotoxic activity

\section{Introduction}

Natural products are an important source of innovative chemical drugs [1]. Finding natural active ingredients for nerve protection and tumor suppression are also hot topics in the current research [2]. The genus Marasmius is a common basidiomycete in tropical and subtropical areas, which belongs to the family Marasmiaceae [3]. A few common species of Marasmius have been studied for searching of bioactive metabolites, and some active compounds such as terpenoids [4-8], steroids [9], cyclic peptides [10], isocoumarins [11] and piperidones [12] have been isolated. Many of these compounds showed antibacterial, cytotoxic and antihypertensive activities [9-12]. Marasmius berteroi is a small orange mushroom belonging to the genus Marasmius, which is widely distributed in the southeast of mainland China, mainly in Hainan, Guangdong, and Taiwan provinces. So far, few researches on chemical constituents of this fungus were reported [13]. To seek for new active small molecules from Marasmius berteroi, the deep chemical investigation on its cultures was thus undertaken, which led to the isolation of three new naphthalene ring compounds dipolynaphthalenes $A-B(\mathbf{1}, \mathbf{2})$ and naphthone $C(\mathbf{3})$ 
along with twelve known analogues (4-15). The isolation process and structural elucidation of three new compounds, as well as their AChE inhibitory and cytotoxic activity, are described in this paper.

\section{Results and Discussion}

Dipolynaphthalene A (compound 1) was isolated as pale-yellow oil. Its molecular formula was assigned to be $\mathrm{C}_{22} \mathrm{H}_{22} \mathrm{O}_{4}$ with twelve degrees of unsaturation according to its positive HR-ESI-MS $\left(\mathrm{m} / \mathrm{z} 373.1412[\mathrm{M}+\mathrm{Na}]^{+}\right.$, calcd. 373.1410 for $\left.\mathrm{C}_{22} \mathrm{H}_{22} \mathrm{O}_{4} \mathrm{Na}\right)$ and NMR spectroscopic data (Table 1). The IR (Supplementary Materials) spectrum revealed the presence of hydroxyl $\left(3305 \mathrm{~cm}^{-1}\right)$ and benzene ring $\left(1581 \mathrm{~cm}^{-1}\right)$ absorptions. The ${ }^{13} \mathrm{C}-\mathrm{NMR}$ and DEPT spectroscopic data (Table 1$)$ showed 22 carbon resonances, including two methoxyls, two $\mathrm{sp}^{3}$ methylenes, ten methines (eight olefinic and one oxygenated), and eight quaternary carbons (three oxygenated). The ${ }^{1} \mathrm{H}-\mathrm{NMR}$ (Table 1) showed the presence of signals for two singlet methoxys $\left(\delta 4.06(3 \mathrm{H}, \mathrm{s}, \mathrm{H}-5), 4.08\left(3 \mathrm{H}, \mathrm{s}, \mathrm{H}-8^{\prime}\right)\right)$. According to a comparison of the corresponding NMR data, compound $\mathbf{1}$ was similar to nodulisporin $B$ [14], a dimer of naphthalene ring compound, except for the two naphthalene rings have different binding sites. Compound 1 was 4,2'-binaphthalene, while nodulisporin B was 2,2'-binaphthalene, which was evidenced by the key HMBC correlations from H-3 $(\delta 2.12 \mathrm{~m}, 2.21 \mathrm{~m})$ to quaternary carbon $\mathrm{C}-2^{\prime}\left(\delta_{\mathrm{C}} 128.1\right), \mathrm{H}-4(\delta 4.74 \mathrm{~m})$ to quaternary carbon $\mathrm{C}-1^{\prime}\left(\delta_{\mathrm{C}} 150.4\right)$. Other correlations in the HMBC (C-5/H-6/H-7/OCH $\left.{ }_{3}, \mathrm{C}-1 / \mathrm{H}-2, \mathrm{H}-1 / \mathrm{C}-8 \mathrm{a} / \mathrm{C}-2, \mathrm{C}-1^{\prime} / \mathrm{H}-4, \mathrm{C}-8^{\prime} / \mathrm{H}-7^{\prime} / \mathrm{H}-6^{\prime}\right)$ and ${ }^{1} \mathrm{H}-{ }^{1} \mathrm{H}$ COSY spectra further supported the atom connectivity in compound 1 (Figures 1 and 2). The relative configuration of compound 1 was determined by ROESY cross-peaks $\mathrm{H}-4\left[\delta_{\mathrm{H}} 4.74(1 \mathrm{H}, \mathrm{m})\right] / \mathrm{H}-3 \alpha\left[\delta_{\mathrm{H}}\right.$ $2.12(1 \mathrm{H}, \mathrm{m})] / \mathrm{H}-2 \alpha\left[\delta_{\mathrm{H}} 1.75(1 \mathrm{H}, \mathrm{m})\right] / \mathrm{H}-3^{\prime}\left[\delta_{\mathrm{H}} 7.23(1 \mathrm{H}, \mathrm{d}, J=8.1)\right], \mathrm{H}-3 \beta\left[\delta_{\mathrm{H}} 2.21(1 \mathrm{H}, \mathrm{m})\right] / \mathrm{H}-2 \beta\left[\delta_{\mathrm{H}} 1.95\right.$ $(1 \mathrm{H}, \mathrm{m})] / \mathrm{H}-1\left[\delta_{\mathrm{H}} 4.85(1 \mathrm{H}, \mathrm{dd}, J=5.4,8.8 \mathrm{~Hz})\right]$. Thus, compound 1 was assigned as shown in Figure 1 and it was named dipolynaphthalene A.

Table 1. ${ }^{1} \mathrm{H}(500 \mathrm{MHz})$ and ${ }^{13} \mathrm{C}-\mathrm{NMR}(125 \mathrm{MHz})$ Data of Compounds 1-2 (in $\left.\mathrm{CDCl}_{3}\right)$.

\begin{tabular}{|c|c|c|c|c|}
\hline \multirow{2}{*}{ No. } & \multicolumn{2}{|r|}{1} & \multicolumn{2}{|c|}{2} \\
\hline & $\delta_{\mathrm{C}}$ & $\delta_{\mathrm{H}}(J$ in $\mathrm{Hz})$ & $\delta_{\mathrm{C}}$ & $\delta_{\mathrm{H}}(J$ in $\mathrm{Hz})$ \\
\hline 1 & 69.7 & $4.85 \mathrm{dd}(5.4,8.8)$ & 67.5 & $4.87 \mathrm{t}(2.7)$ \\
\hline $2 \alpha$ & 29.2 & $1.75 \mathrm{~m}$ & 26.8 & $1.81 \mathrm{~m}$ \\
\hline $2 \beta$ & & $1.95 \mathrm{~m}$ & & $1.75 \mathrm{~m}$ \\
\hline $3 \alpha$ & 26.2 & $2.12 \mathrm{~m}$ & 23.6 & $2.37 \mathrm{~m}$ \\
\hline $3 \beta$ & & $2.21 \mathrm{~m}$ & & $1.85 \mathrm{~m}$ \\
\hline 4 & 33.6 & $4.74 \mathrm{~m}$ & 33.9 & $5.03 \mathrm{~d}(5.4)$ \\
\hline $4 a$ & 127.8 & & 134.2 & \\
\hline 5 & 156.2 & & 157.3 & \\
\hline 6 & 109.9 & $6.74 \mathrm{~d}(8.0)$ & 103.9 & $6.85 \mathrm{~d}(8.0)$ \\
\hline 7 & 127.4 & $7.27 \mathrm{t}(8.0)$ & 125.6 & $7.45 \mathrm{t}(8.0)$ \\
\hline 8 & 119.5 & $7.26 \mathrm{~d}(8.0)$ & 118.0 & $7.9 \mathrm{~d}(8.0)$ \\
\hline $8 a$ & 141.9 & & 140.5 & \\
\hline $5-\mathrm{OCH}_{3}$ & 56.2 & $4.06 \mathrm{~s}$ & 55.7 & $3.49 \mathrm{~s}$ \\
\hline $1^{\prime}$ & 150.4 & & 152.9 & \\
\hline $2^{\prime}$ & 128.1 & & 110.4 & $6.79 \mathrm{~d}(8.0)$ \\
\hline $3^{\prime}$ & 124.7 & $7.23 \mathrm{~d}(8.1)$ & 126.8 & $6.37 \mathrm{~d}(8.0)$ \\
\hline $4^{\prime}$ & 117.8 & $7.11 \mathrm{~d}(8.1)$ & 128.3 & \\
\hline $4^{\prime} \mathrm{a}$ & 135.3 & & 131.6 & \\
\hline $5^{\prime}$ & 109.8 & $6.74 \mathrm{~d}(7.8)$ & 121.7 & $7.11 \mathrm{~d}(7.8)$ \\
\hline $6^{\prime}$ & 121.9 & $7.34 \mathrm{~d}(7.8)$ & 127.9 & $7.32 \mathrm{t}(7.8)$ \\
\hline $7^{\prime}$ & 103.8 & $6.76 \mathrm{~d}(7.8)$ & 109.5 & $6.60 \mathrm{~d}(7.8)$ \\
\hline $8^{\prime}$ & 157.4 & & 157.0 & \\
\hline $8^{\prime} \mathrm{a}$ & 115.0 & & 115.7 & \\
\hline $8^{\prime}-\mathrm{OCH}_{3}$ & 55.7 & $4.08 \mathrm{~s}$ & 56.3 & $3.49 \mathrm{~s}$ \\
\hline
\end{tabular}




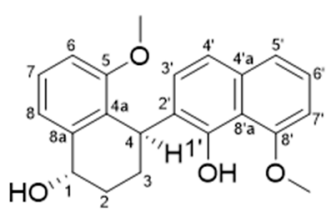

1<smiles>[R]c1ccc2cccc([R])c2c1[R]</smiles>

$5 \quad \mathrm{R}_{1}=\mathrm{OCH}_{3} \quad \mathrm{R}_{2}=\mathrm{OCH}_{3} \quad \mathrm{R}_{3}=\mathrm{H}$

$6 \quad \mathrm{R}_{1}=\mathrm{OCH}_{3} \quad \mathrm{R}_{2}=\mathrm{OH} \quad \mathrm{R}_{3}=\mathrm{H}$

$\begin{array}{lll}7 \mathrm{R}_{1}=\mathrm{OH} & \mathrm{R}_{2}=\mathrm{OCH}_{3} & \mathrm{R}_{3}=\mathrm{OH}\end{array}$<smiles>O=C1CC[C@H](O)c2cc(O)cc(O)c21</smiles>

11<smiles>O=C1CC(O)[C@H](O)c2cccc(O)c21</smiles>

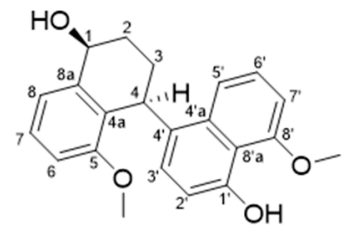

2

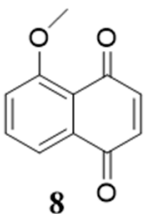

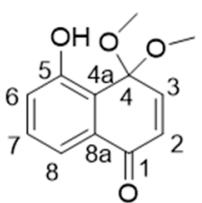

3<smiles>O=C1CCCc2cccc(O)c21</smiles>

9

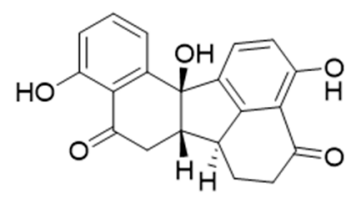

4<smiles>COc1cccc2c1[C@@H](O)CCC2=O</smiles>

10<smiles>O=C1C[C@H](O)Cc2cc(O)cc(O)c21</smiles>

13<smiles>COc1cccc2c1C(=O)CC[C@H]2O</smiles>

14<smiles>O=C1C[C@@H](O)[C@H](O)c2cc(O)cc(O)c21</smiles>

15

Figure 1. The structures of compounds 1-15.
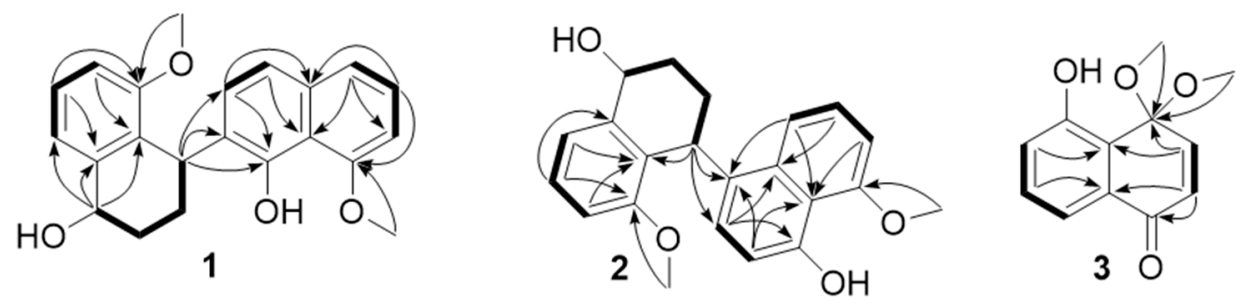

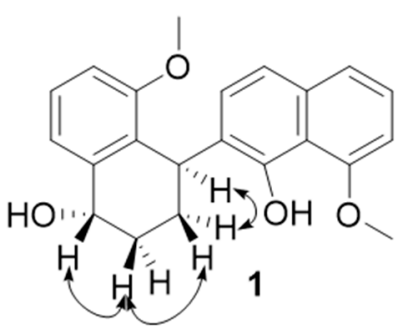

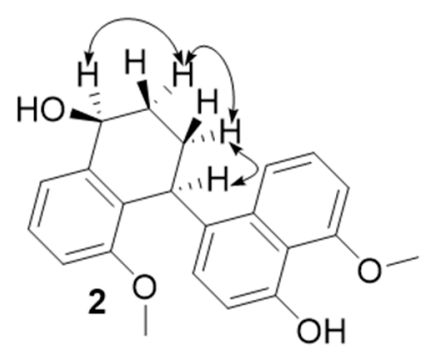

Figure 2. Key ${ }^{1} \mathrm{H}_{-}{ }^{1} \mathrm{H}$ COSY $(--), \operatorname{HMBC}(\mathrm{H} \rightarrow \mathrm{C})$, and ROESY $(\leftrightarrow)$ correlations of $\mathbf{1}-\mathbf{3}$.

Dipolynaphthalene B (compound 2) was purified as pale yellow oil, and possessed the molecular formula $\mathrm{C}_{22} \mathrm{H}_{22} \mathrm{O}_{4}$ based on HR-ESI-MS $\left(\mathrm{m} / \mathrm{z} 373.1410[\mathrm{M}+\mathrm{Na}]^{+}\right.$, calcd for $\mathrm{C}_{22} \mathrm{H}_{22} \mathrm{O}_{4} \mathrm{Na}$, 373.1410) with twelve degrees of unsaturation. The IR spectrum showed the presence of hydroxyl $\left(3399 \mathrm{~cm}^{-1}\right)$ and benzene ring $\left(1583 \mathrm{~cm}^{-1}\right)$ absorptions. The ${ }^{13} \mathrm{C}$-NMR spectrum of 2 displayed 22 carbon resonances extremely similar to those of compound 1 , suggesting that both of them were dimeric naphthalene rings. The only difference was that compound 2 was 4,4'-binaphthalene instead of 4,2'-binaphthalene in 1, which was further supported by the HMBC correlations (Figure 2) from H-4 [ $\delta 5.03 \mathrm{~d}(5.4)]$ to $C-3^{\prime}\left(\delta_{C} 126.8\right)$ and $C-4^{\prime}$ a $\left(\delta_{C} 131.6\right), \mathrm{H}-3(\delta 1.85 \mathrm{~m})$ to $C-4^{\prime}\left(\delta_{\mathrm{C}} 128.3\right)$. Other correlations in the $\mathrm{HMBC}$ and ${ }^{1} \mathrm{H}-{ }^{1} \mathrm{H}$ COSY spectra (Figure 2 ) further supported the atom connectivity in compound 2. The configurations of $1-\alpha \mathrm{OH}$ and $4-\beta \mathrm{H}$ in 2 were deduced from its ROESY cross-peaks (Figure 2) 
$\mathrm{H}-1 \alpha / \mathrm{H}-2 \alpha\left[\delta_{\mathrm{H}} 1.81(1 \mathrm{H}, \mathrm{m})\right] / \mathrm{H}-3 \alpha\left[\delta_{\mathrm{H}} 2.37(1 \mathrm{H}, \mathrm{m})\right] / \mathrm{H}-4\left[\delta_{\mathrm{H}} 5.03(1 \mathrm{H}, \mathrm{d}, J=5.4 \mathrm{~Hz})\right]$. Thus, compound 2 was assigned as shown in Figure 1, and named dipolynaphthalene B.

In order to determine the absolute configurations of $\mathbf{1}$ and $\mathbf{2}$, the ECD spectra were calculated by the TDDFT method at the apfd/6-311+g (2d, p) level. The calculated ECD spectra of $\mathbf{1}$ and $\mathbf{2}$ are generally consistent with their measured spectra (Figure 3), implying the $(1 S, 4 R)$ - configuration for 1 and the (1S,4S)- configuration for $\mathbf{2}$ (Figure 3). However, much more work was needed to confirm the absolute configurations of $\mathbf{1}$ and $\mathbf{2}$, for there are also some differences present between the calculated and measured ECD spectra.
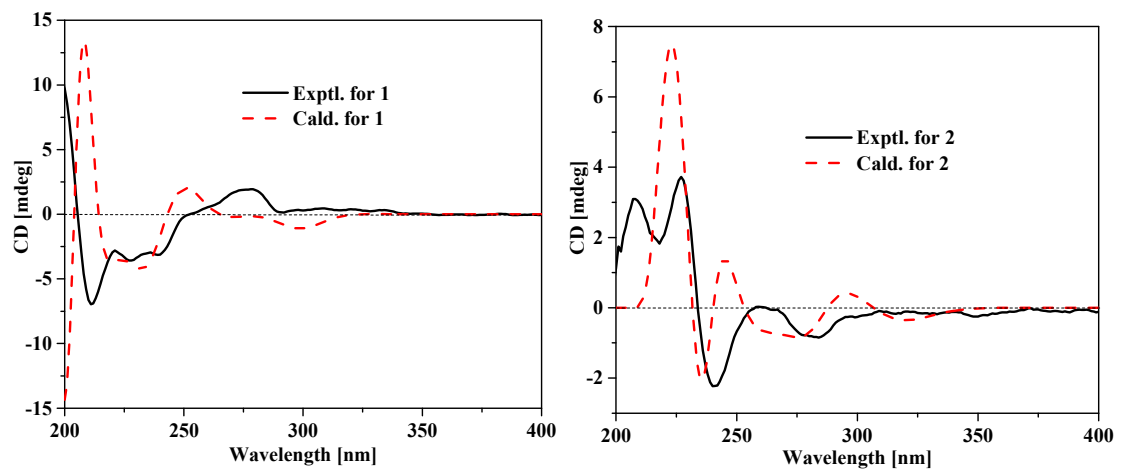

Figure 3. Experimental and calculated ECD spectra for compounds $\mathbf{1}$ and $\mathbf{2}$.

Naphthone C (3) was isolated as pale yellow oil, which molecular formula was assigned to be $\mathrm{C}_{12} \mathrm{H}_{12} \mathrm{O}_{4}$ with seven degrees of unsaturation according to its positive HR-ESI-MS $(\mathrm{m} / \mathrm{z}$ $243.0622[\mathrm{M}+\mathrm{Na}]^{+}$, calcd. 243.0628 for $\mathrm{C}_{12} \mathrm{H}_{12} \mathrm{O}_{4} \mathrm{Na}$ ) and NMR spectroscopic data (Table 2). The IR spectrum revealed the presence of hydroxyl $\left(3323 \mathrm{~cm}^{-1}\right)$, carbonyl $\left(1714 \mathrm{~cm}^{-1}\right)$ and double bond $\left(1677 \mathrm{~cm}^{-1}\right)$ absorptions. The ${ }^{13} \mathrm{C}-\mathrm{NMR}$ and DEPT spectroscopic data (Table 2$)$ showed 12 carbon resonances, including two methoxyls, five methines, and five quaternary carbons (two oxygenated and one carbonyl carbon), which was inferred that the basic skeleton of compound 3 was naphthone. The ${ }^{1} \mathrm{H}-\mathrm{NMR}$ (Table 2) showed the presence of signals for singlet methoxy $(\delta 3.35(3 \mathrm{H}$, $\mathrm{s}, \mathrm{H}-4)$ ). According to a comparison of the corresponding NMR data, compound 3 was similar to 4,4,5-trimethoxy-1(4H)-naphthone [15], a derivative of naphthalene ring compound, except for the hydroxyl (C-5 $\left.\delta_{\mathrm{C}} 157.9\right)$ in 3 instead of methoxy in 4,4,5-trimethoxy-1 $(4 H)$-naphthone, which was further supported by the HMBC correlations (Figure 2$)$ from $\mathrm{H}-6\left[\delta_{\mathrm{H}} 6.94 \mathrm{dd}(8.3,1.06)\right]$ to $\mathrm{C}-5\left(\delta_{\mathrm{C}} 157.9\right)$ and $\mathrm{H}-7\left[\delta_{\mathrm{H}} 7.27 \mathrm{t}(7.5)\right]$ to $\mathrm{C}-5$. Other correlations in the HMBC further supported the atom connectivity in compound. Thus, compound 3 was assigned as shown in Figure 1, and named naphthone C.

Table 2. ${ }^{1} \mathrm{H}(500 \mathrm{MHz})$ and ${ }^{13} \mathrm{C}-\mathrm{NMR}(125 \mathrm{MHz})$ Data of Compounds 3 (in $\left.\mathrm{CDCl}_{3}\right)$.

\begin{tabular}{ccc}
\hline \multirow{2}{*}{ No. } & \multicolumn{2}{c}{3} \\
\cline { 2 - 3 } & $\delta_{\mathrm{C}}$ & $\delta_{\mathbf{H}}(\boldsymbol{J}$ in Hz) \\
\hline 1 & $193.3(\mathrm{~s})$ & \\
2 & $145.3(\mathrm{~d})$ & $7.24 \mathrm{~d}(9.9)$ \\
3 & $124.6(\mathrm{~d})$ & $6.07 \mathrm{~d}(9.9)$ \\
4 & $97.5(\mathrm{~s})$ & \\
$4 \mathrm{a}$ & $119.4(\mathrm{~s})$ & \\
5 & $157.9(\mathrm{~s})$ & \\
6 & $120.2(\mathrm{~d})$ & $6.94 \mathrm{dd}(8.3,1.0)$ \\
7 & $131.7(\mathrm{~d})$ & $7.27 \mathrm{t}(7.5)$ \\
8 & $122.6(\mathrm{~d})$ & $6.83 \mathrm{dd}(8.3,1.0)$ \\
$8 \mathrm{a}$ & $132.6(\mathrm{~s})$ & \\
$\mathrm{OCH}_{3}$ & $52.3(\mathrm{q})$ & $3.35 \mathrm{~s}$ \\
\hline
\end{tabular}


The twelve known compounds (4-15) was determined to be daldinone $C$ (4) [16], 1,8-dimethoxynaphthalene (5) [17], 8-methoxy-1-naphthol (6) [18], 8-methoxynaphthalen e-1,7 -diol (7) [19], 5-methoxy-1,4-naphthoquinone (8) [20], isosclerone (9) [21], 5-O-methylsclerone (10) [22] 4,6,8-trihydroxy-3,4-dihydronaphthalen-1(2H)-one(6-hydroxy-isosclerone) (11) [23], trans-3,4-dihydro-3,4,8-trihydroxynaphthalene-1-(2H)-one(12) [24], scytalone (13) [25], xylarenone (14) [26] and cis-4-hydroxyscytalone (15) [27] by comparison of its spectroscopic data with those of literature.

The acetylcholinesterase inhibitory activity of compounds 1-15 were tested by previous method as described in the literature [28]. The results showed that compounds $\mathbf{2 - 4}$ and compound $\mathbf{7}$ exhibited anti-acetylcholinesterase activities at a concentration of $50 \mu \mathrm{g} / \mathrm{mL}$ with inhibition ratios of $42.74 \%$, $44.63 \%, 9.50 \%$, and $51.49 \%$, respectively (Table 3). In the screening test of cytotoxicity [29], compounds $5,7,8$ showed inhibitory activity against two tumor cell lines, with $\mathrm{IC}_{50}$ of $0.10,0.076$ and $0.058 \mathrm{mM}$ (K562) and 0.13, 0.18, and 0.15 mM (SGC-7901), respectively (Table 4). Binaphthalenes are dimeric compounds of naphthalene ring, mainly derivatives of DHN and juglone formed by different linking modes [30]. The acetylcholinesterase inhibitory activity evaluation results showed that compounds 2 and 4 exhibited anti-acetylcholinesterase activities, while compound 1 was inactive. Structurally, the active compounds 2 and $\mathbf{4}$ were naphthalene ring dimers with para-para ligation, while compound 1 was ortho-para ligation dimer, which indicated that the polymeric sites in binaphthalene compounds were very important for their biological activity. In the cytotoxic assay, compound 8 were active, while 9-15 were inactive, which may suggest that the 1,4-dione moiety is essential for their cytotoxicity.

Table 3. The inhibitory activity of compounds 1-15 against AChE.

\begin{tabular}{ccc}
\hline Compound & Inhibition Rate (\%) & Initial Screening Concentration (Final Concentration)/ $\boldsymbol{\mu M}$ \\
\hline & $21.35 \pm 0.57$ & 143 \\
2 & $42.74 \pm 0.93$ & 143 \\
3 & $44.63 \pm 0.52$ & 227 \\
4 & $39.50 \pm 2.14$ & 149 \\
5 & $12.40 \pm 0.60$ & 266 \\
6 & $24.74 \pm 1.70$ & 287 \\
7 & $51.49 \pm 0.32$ & 263 \\
8 & $13.72 \pm 1.52$ & 266 \\
9 & $14.51 \pm 5.20$ & 281 \\
10 & $17.69 \pm 0.89$ & 260 \\
11 & $14.87 \pm 3.14$ & 258 \\
12 & $13.33 \pm 1.46$ & 258 \\
13 & $15.18 \pm 2.91$ & 258 \\
14 & $10.59 \pm 3.97$ & 260 \\
15 & $11.80 \pm 4.10$ & 238 \\
Tacrine & $71.79 \pm 1.11$ & 0.33 \\
\hline
\end{tabular}

Table 4. Cytotoxic activities of compounds 1-15 against K562 and SGC-7901 cell lines ( $\left.\mathrm{IC}_{50}, \mathrm{mM}\right)$.

\begin{tabular}{ccc}
\hline Compound & K562 & SGC-7901 \\
\hline 1 & $>0.25$ & $>0.25$ \\
2 & $>0.25$ & $>0.25$ \\
3 & $>0.25$ & $>0.25$ \\
4 & $>0.25$ & $>0.25$ \\
5 & 0.10 & 0.13 \\
6 & $>0.25$ & $>0.25$ \\
7 & 0.076 & 0.18 \\
8 & 0.058 & 0.15 \\
9 & $>0.25$ & $>0.25$ \\
10 & $>0.25$ & $>0.25$ \\
11 & $>0.25$ & $>0.25$ \\
12 & $>0.25$ & $>0.25$ \\
13 & $>0.25$ & $>0.25$ \\
14 & $>0.25$ & $>0.25$ \\
15 & $>0.25$ & $>0.25$ \\
taxol & 0.00021 & 0.0010 \\
\hline
\end{tabular}




\section{Materials and Methods}

\subsection{General Information}

Optical rotations were measured with a Rudolph Autopol III polarimeter (Rudolph Research Analytical, Hackettstown, NJ, USA). Shimadzu UV-2550 spectrometer (Beckman, Brea, CA, USA) was used for scanning UV spectroscopy. IR spectra were obtained on a Tensor 27 spectrometer, as $\mathrm{KBr}$ pellets (Thermo, Pittsburgh, PA, USA). NMR spectra were recorded on an AV-500 spectrometer (Bruker, Bremen, Germany) with TMS (Tetramethylsilane) as an internal standard. HR-ESI-MS were performed on an API QSTAR Pulsar mass spectrometer (Billerica, MA, USA). Silica gel (200-300 mesh, Qingdao Marine Chemical Inc., Qingdao, China), RP-18 (40-70 mm, Fuji Silysia Chemical Ltd., Kasugai Aichi, Japan) and Sephadex LH-20 (GE Healthcare, Uppsala, Sweden) were used for column chromatography (CC). Semipreparative HPLC (Agilent 1100, Agilent Technologies Inc., Santa Clara, CA, USA) was performed on an Agilent 1100 liquid chromatograph with a Zorbax SB-C $18,9.4 \mathrm{~mm} \times 25 \mathrm{~cm}$, column. Fractions were monitored by TLC and spots were visualized by heating after spraying with $5 \% \mathrm{H}_{2} \mathrm{SO}_{4}$ in ethanol.

\subsection{Fungal Material}

The fungus Marasmius berteroi was collected in the valley of Yinggeling, Hainan province of China, in November 2015, and identified by Associate Professor Sheng-zhuo Huang, the Institute of Tropical Bioscience and Biotechnology, Chinese Academy of Tropical Agricultural Sciences. The mycelium was isolated from the Marasmius berteroi and its strain was maintained on potato dextrose agar (PDA) slant at $4{ }^{\circ} \mathrm{C}$. A voucher specimen (YGL-18) was deposited at the Institute of Tropical Bioscience and Biotechnology, Chinese Academy of Tropical Agricultural Sciences, Haikou, China.

\subsection{Fermentation, Extraction and Isolation}

The fungus was cultured on slants of PDA medium at $28^{\circ} \mathrm{C}$ for 5 days. Plugs of agar supporting mycelium growth were cut and transferred aseptically to $200 \times 1000 \mathrm{~mL}$ Erlenmeyer flasks each containing $300 \mathrm{~mL}$ medium. The flask was incubated at room temperature under static conditions for 30 days. The culture broth $(60 \mathrm{~L})$ was filtered to give the filtrate and mycelia. The filtrate was evaporated in vacuo to a small volume and then suspended in $\mathrm{H}_{2} \mathrm{O}$ and partitioned successively with EtOAc and n-BuOH. The EtOAc solution was evaporated under reduced pressure to give a crude extract $(32.0 \mathrm{~g})$, which was separated into fractions 1-6 on silica gel CC using a gradient eluent of petroleum ether-EtOAc (15:1-1:1, v/v, each $3 \mathrm{~L})$. Fr. 2 (7.5 g) was subjected to repeated RP-18 CC (eluted with $\mathrm{MeOH} / \mathrm{H}_{2} \mathrm{O}$ from 2:8 to 10:0, $/ v$, each $500 \mathrm{~mL}$ ) and silica gel CC (eluted with petroleum ether-EtOAc from 5:1 to 1:1, v/v, each $600 \mathrm{~mL}$ ) to afford compounds 1 (7.0 mg), 2 (5.0 mg) and 4 (3.0 mg). Fr. 3 (6.0 g) was applied to octadecyl silane (ODS) gel with gradient elution of $\mathrm{MeOH}-\mathrm{H}_{2} \mathrm{O}(1: 5,2: 3,3: 2$, $4: 1,1: 0)$ to yield compounds $3(4.0 \mathrm{mg}), 6(8.0 \mathrm{mg})$ and $7(2.0 \mathrm{mg})$. Fr. $4(5.0 \mathrm{~g})$ was purified by HPLC over an ODS column (30-85\% MeOH/H $\left.\mathrm{H}_{2} \mathrm{O}, v / v\right)$ to give compounds $5(4 \mathrm{mg}), 8(8.0 \mathrm{mg}), 9(2.0 \mathrm{mg})$ and $11(2.0 \mathrm{mg})$. Fr.5 (3.5 g) was purified by HPLC over an ODS column $\left(30-75 \% \mathrm{MeOH} / \mathrm{H}_{2} \mathrm{O}, v / v\right)$ to give compound 10 (4 mg) and 12 (2 mg). The compounds $13(3 \mathrm{mg}), 14(9.0 \mathrm{mg}), 15(4.0 \mathrm{mg})$ were purified from Fr.6 (5 g) by HPLC over an ODS column (30-75\% $\left.\mathrm{MeOH} / \mathrm{H}_{2} \mathrm{O}, v / v\right)$.

\subsubsection{Dipolynaphthalene A (1)}

Pale yellow oil; $[\alpha]_{\mathrm{D}}^{25}-14$ (c 0.10, MeOH); IR (KBr) $v_{\max } 3305,2947,2346,2301,1735,1661$, 1581, 1459, 1258, $1015 \mathrm{~cm}^{-1} ;{ }^{1} \mathrm{H}$ - and ${ }^{13} \mathrm{C}-\mathrm{NMR}$ data see Table 1 ; ESI-MS positive $\mathrm{m} / z[\mathrm{M}+\mathrm{Na}]^{+} 373$; HR-ESI-MS $m / z[\mathrm{M}+\mathrm{Na}]^{+} 373.1412$ (calcd for $\mathrm{C}_{22} \mathrm{H}_{22} \mathrm{O}_{4} \mathrm{Na}, 373.1410$ ). 


\subsubsection{Dipolynaphthalene B (2)}

Pale yellow oil; $[\alpha]_{\mathrm{D}}^{25}-8$ (c 0.10, MeOH); IR (KBr) $v_{\max } 3399,2943,2366,2344,1657,1618,1583,1467$, $1407,1258 \mathrm{~cm}^{-1} ;{ }^{1} \mathrm{H}$ - and ${ }^{13} \mathrm{C}-\mathrm{NMR}$ data see Table 1 ; ESI-MS positive $m / z[\mathrm{M}+\mathrm{Na}]^{+} 373$; HR-ESI-MS $m / z[\mathrm{M}+\mathrm{Na}]^{+} 373.1410$ (calcd for $\mathrm{C}_{22} \mathrm{H}_{22} \mathrm{O}_{4} \mathrm{Na}, 373.1410$ ).

\subsubsection{Naphthone C (3)}

Pale yellow oil; $[\alpha]_{\mathrm{D}}^{25}-42.9$ (c 0.15, MeOH); IR (KBr) $v_{\max } 3323,2354,2319,1714,1677,1577,1461$, $1273 \mathrm{~cm}^{-1} ;{ }^{1} \mathrm{H}$ - and ${ }^{13} \mathrm{C}-\mathrm{NMR}$ data see Table 2; ESI-MS positive $\mathrm{m} / z$ [M + Na] ${ }^{+}$243; HR-ESI-MS m/z [M $+\mathrm{Na}]^{+} 243.0622$ (calcd for $\mathrm{C}_{15} \mathrm{H}_{24} \mathrm{O}_{5} \mathrm{Na}, 243.0628$ ).

\subsection{Bioassay of AChE Inhibitory Activity and Cytotoxic Activity}

AChE inhibitory activity of these compounds was assayed by the spectrophotometric method developed by Ellman [28]. Acetylthiocholine iodide (Sigma, St. Louis, MO, USA) was used as substrate in the assay. $\mathrm{Na}_{2} \mathrm{HPO}_{4}(94.7 \mathrm{~mL}, 0.1 \mathrm{M})$ and $\mathrm{NaH}_{2} \mathrm{PO}_{4}(5.3 \mathrm{~mL}, 0.1 \mathrm{M})$ were mixed to get phosphate buffer (PB, pH 8.0). Compounds were dissolved in DMSO (2\% in PB). The reaction mixture contained PB $(110 \mu \mathrm{L})$, test compound solution $(10 \mu \mathrm{L}, 2000 \mu \mathrm{M})$ and acetyl cholinesterase solution $(40 \mu \mathrm{L}$, $0.1 \mathrm{U} / \mathrm{mL})$, which were mixed and incubated for $20 \mathrm{~min}\left(30^{\circ} \mathrm{C}\right)$. The reaction was initiated by the addition of DTNB (5,5-dithiobis-2-nitrobenzoic acid, $20 \mu \mathrm{L}, 6.25 \mathrm{mM})$ and acetylthiocholine iodide $(20 \mu \mathrm{L}, 6.25 \mathrm{mM})$. The hydrolysis of acetylthiocholine was monitored at $405 \mathrm{~nm}$ every $30 \mathrm{~s}$. Tacrine (Sigma-Aldrich 99\%) was used as positive control (final concentration $0.33 \mu \mathrm{M}$ ), while $2 \%$ DMSO in PB was set as negative control (NC). All reactions were performed in triplicate. The percentage inhibition was calculated as follows: \% age inhibition $=(E-S) / E \times 100(E$ is activity of the enzyme without test compound and $S$ is the activity of enzyme with test compound).

The cytotoxicities of compounds 1-15 (purity of tested compounds over 95\%) were assessed using the MTT [3-4,5-dimethylthiazol-2-yl)-2,5-diphenyltetrazolium bromide] assay against human cell lines K562, BEL7702, andSGC7901 according to the method described in previous literature [29] Taxol (Kyowa Hakko Kogyo Co., Tokyo, Japan; purity 99\%) was used as a positive control.

\section{Conclusions}

The secondary metabolites of fungi were various, which were good sources of active substances. The special compounds isolated from Marasmius berteroi also showed the diversity of the genus Marasmius. In the present study, three new naphthalene compounds dipolynaphthalenes A-B (1-2) and naphthone C (3), as well as 12 known compounds were isolated from the mycelial fermentation products of Marasmius berteroi. The bioactivity evaluation assays showed that dipolynaphthalene B (2), naphthone C (3), daldinone C (4) and 8-methoxynaphthalene-1,7-diol (7) showed anti-acetylcholinesterase activities.

Supplementary Materials: The following are available online. Figure S1: ${ }^{1} \mathrm{H}-\mathrm{NMR}$ spectrum of dipolynaphthalene A (1); Figure S2: ${ }^{13}$ C-NMR spectrum of dipolynaphthalene A (1); Figure S3: HSQC spectrum ofdipolynaphthalene A (1); Figure S4: HMBC spectrum ofdipolynaphthalene A (1); Figure S5: ${ }^{1} \mathrm{H}-{ }^{1} \mathrm{H}$ COSY spectrum of dipolynaphthalene A (1); Figure S6: ROESY spectrum of dipolynaphthalene A (1); Figure S7: HR-ESI-MS of dipolynaphthalene A (1); Figure S8: IR spectrum of dipolynaphthalene A (1); Figure S9: ${ }^{1} \mathrm{H}-\mathrm{NMR}$ spectrum of dipolynaphthalene B (2); Figure S10: ${ }^{13}$ C-NMR spectrum of dipolynaphthalene B (2); Figure S11: HSQC spectrum ofxylariaine B (2); Figure S12: HMBC spectrum of dipolynaphthalene B (2); Figure S13: ${ }^{1} \mathrm{H}-{ }^{1} \mathrm{H}$ COSY spectrum of dipolynaphthalene B (2); Figure S14: ROESY spectrum of dipolynaphthalene B (2); Figure S15: HR-ESI-MS of dipolynaphthalene B (2); Figure S16: IR spectrum of dipolynaphthalene B (2); Figure S17: ${ }^{1} \mathrm{H}-\mathrm{NMR}$ spectrum ofnaphthone C (3); Figure S18: ${ }^{13}$ C-NMR spectrumof naphthone C (3); Figure S19: HSQC spectrum of naphthone C (3); Figure S20: HMBC spectrum of naphthone C (3); Figure S21: ${ }^{1} \mathrm{H}^{1}{ }^{\mathrm{H}}$ COSY spectrum ofnaphthone C (3); Figure S22: HR-ESI-MS of naphthone C (3); Figure S23: IR spectrum of naphthone C (3).

Author Contributions: N.N.Y.: wrote the manuscript and isolate compounds; Q.Y.M.: activity test; F.D.K.: structural elucidation; Q.Y.X.: method adviser; H.F.D.: data analysi; L.M.Z.: data analysis; Z.F.Y.: revised the 
manuscript; Y.X.Z.: theory and orientation adviser. All authors have read and agree to the published version of the manuscript.

Funding: This research received no external funding.

Acknowledgments: This work was supported by Key Research \& Development Program of Hainan Province (ZDYF2019127), Financial Fund of the Ministry of Agriculture and Rural Affairs, P. R. of China (NFZX2018), China Agriculture Research System (CARS-21) and Central Public-interest Scientific Institution Basal Research Fund for Chinese Academy of Tropical Agricultural Sciences (17CXTD-15, 1630052016008).

Conflicts of Interest: The authors declare no conflict of interest.

\section{References}

1. Liu, R.X.; Chang, P.; Jiang, Z.F. Research Progress of Bioactive Polysaccharides in Neuroprotection and in the Prevention and Treatment of Alzheimer's Disease. Nat. Prod. Res. Dev. 2014, 26, 2076-2081.

2. Hiremathad, A.; Piemontese, L. Heterocyclic compounds as key structures for the interaction with old and new targets in Alzheimer's disease therapy. Neural Regen. Res. 2017, 12, 1256-1261. [PubMed]

3. Song, B.; Deng, C.Y.; Wu, X.L.; Li, T.H. Known Species of Marasmius from China and Their Distribution. Guizhou Sci. 2009, 27, 1-18.

4. Ayer, W.A.; Craw, P.A.; Stout, T.J.; Clardy, J. Novel sesquiterpenoids from the fairy ring fungus, Marasmius oreades. Can. J. Chem. 1989, 67, 773-778. [CrossRef]

5. Evans, L.; Hedger, J.; O’Donnell, G.; Skelton, B.W.; White, A.H.; Williamson, R.T.; Gibbons, S. Structure elucidation of some highly unusual tricyclic cis-caryophyllane sesquiterpenes from Marasmiellus troyanus. Tetrahedron Lett. 2010, 51, 5493-5496. [CrossRef]

6. Meng, J.; Li, Y.Y.; Ou, Y.X.; Song, L.F.; Lu, C.H.; Shen, Y.M. New sesquiterpenes from Marasmius cladophyllus. Mycology 2011, 2, 30-36. [CrossRef]

7. Liermann, J.C.; Thines, E.; Opatz, T.; Anke, H. Drimane sesquiterpenoids from Marasmius sp. inhibiting the conidial germination of plant-pathogenic fungi. J. Nat. Prod. 2012, 75, 1983-1986. [CrossRef]

8. Isaka, M.; Palasarn, S.; Sappan, M.; Supothina, S.; Boonpratuang, T. Hirsutane sesquiterpenes from cultures of the basidiomycete Marasmiellus sp. BCC 22389. Nat. Prod. Bioprospect. 2016, 6, 257-260. [CrossRef]

9. Fattorusso, E.; Giovannitti, B.; Lanzotti, V.; Magno, S.; Violante, U. 4,4-Dimethyl-5 alpha -ergosta -8,24(28)-dien-3 beta-ol from the fungus Marasmius oreades. Steroids 1992, 57, 119-121. [CrossRef]

10. Ványolós, A.; Dékány, M.; Kovács, B.; Krámos, B.; Bérdi, P.; Zupkó, I.; Hohmann, J.; Béni, Z. Gymnopeptides A and B, cyclic octadecapeptides from the mushroom Gymnopus fusipes. Org. Lett. 2016, 18, 2688-2691. [CrossRef]

11. Thongbai, B.; Surup, F.; Mohr, K.; Kuhnert, E.; Hyde, K.D.; Stadler, M. Gymnopalynes A and B, chloropropynyl-isocoumarin antibiotics from cultures of the basidiomycete Gymnopus sp. J. Nat. Prod. 2013, 76, 2141-2144. [CrossRef] [PubMed]

12. Zhang, L.; Yang, M.; Song, Y.; Sun, Z.; Peng, Y.; Qu, K.; Zhu, H. Antihypertensive effect of 3,3,5,5-tetramethyl-4-piperidone, a new compound extracted from Marasmius androsaceus. J. Ethnopharmacol. 2009, 123, 34-39. [CrossRef] [PubMed]

13. Mao, X.L. Macromycetes of China, 1st ed.; Science Press: Beijing, China, 2009.

14. Dai, J.; Karsten, K.; Ulrich, F.; Siegfried, D.; Barbara, S.; Attila, K.S.; Sándor, A.; Tibor, K.; Van Ree, T. Metabolites from the endophytic fungus Nodulisporium sp. from Juniperus cedre. Eur. J. Org. Chem. 2006, 15, 3498-3506. [CrossRef]

15. Crouse, D.J.; Wheeler, D.M.S. Preparation of a 4-monoketal of juglone methyl ether. Tetrahedron Lett. 1979, 20, 4797-4798. [CrossRef]

16. Gu, W.; Ge, H.M.; Song, Y.C.; Ding, H.; Zhu, H.L.; Zhao, X.A.; Tan, R.X. Cytotoxic benzo[j]fluoranthene metabolites from Hypoxylon truncatum IFB-18, an endophyte of Artemisia annua. J. Nat. Prod. 2007, 70, 114-117. [CrossRef]

17. Li, D.L.; Wu, Z.C.; Chen, Y.C.; Tao, M.H.; Zhang, W.M. Chemical constituents of endophytic fungus Nodulisporium sp. A4 from Aquilaria sinensis. China J. Chin. Mater. Med. 2011, 36, 3276-3280.

18. Nadeau, A.K.; Sorensen, J.L. Polyketides produced by Daldinia loculata cultured from Northern Manitoba. Tetrahedron Lett. 2011, 52, 1697-1699. [CrossRef] 
19. Chang, C.; Chang, H.; Cheng, M. Inhibitory effects of constituents of an endophytic fungus Hypoxylon investiens on nitric oxide and interleukin-6 production in RAW264.7 macrophages. Chem. Biodivers. 2014, 11, 949-961. [CrossRef]

20. Tietze, L.F.; Güntner, C.; Gericke, K.M. A Diels-Alder reaction for the total synthesis of the novel antibiotic antitumor agent mensacarcin. Eur. J. Org. Chem. 2005, 2005, 2459-2467. [CrossRef]

21. William, A.A.; Latchezar, S.T.; Leonard, J.H. Metabolites from a wood-inhabiting cup fungus, Urnula craterium. Nat. Prod. Lett. 2000, 14, 405-410.

22. Arai, M.; Yamamoto, K.; Namatame, I. New monordens produced by amidepsine-producing fungus Humicola sp. FO-2942. J. Antibiot. 2003, 56, 526-532. [CrossRef] [PubMed]

23. Dong, J.Y.; Song, H.C.; Li, J.H. Ymf 1029A-E, preussomerin analogues from the fresh-water-derived fungus YMF 1.01029. J. Nat. Prod. 2008, 71, 952-956. [CrossRef] [PubMed]

24. Couché, E.; Fkyerat, A.; Tabacchi, R. Stereoselective synthesis of cis- and trans-3,4-dihydro-3, 4,8-trihydroxynaphthalen-1(2H)-one. Helv. Chim. Acta 2010, 92, 903-917. [CrossRef]

25. Li, X.J.; Gao, J.M.; Zhang, A.L. Toxins from a symbiotic fungus, Leptographium qinlingensis associated with Dendroctonus armandi and their in vitro toxicities to Pinus armandi seedlings. Eur. J. Plant Pathol. 2012, 134, 239-247. [CrossRef]

26. Rukachaisirikul, V.; Sommart, U.; Phongpaichit, S. Metabolites from the xylariaceous fungus PSU-A80. Chem. Pharm. Bull. 2007, 55, 1316-1318. [CrossRef] [PubMed]

27. Huang, R.; Wang, T.; Xie, X.S. Secondary metabolites from an endophytic fungus Nigrospora sp. Chem. Nat. Compd. 2016, 52, 697-699. [CrossRef]

28. Ellman, G.L.; Courtney, K.D.; Andres, V.; Featherstone, R.M. A new and rapid colorimetric determination of acetylcholinesterase activity. Biochem. Pharmacol. 1961, 7, 88-95. [CrossRef]

29. Mosmann, T. Rapid colorimetric assay for cellular growth and survival: Application to proliferation and cytotoxicity assays. J. Immunol. Methods 1983, 65, 55-63. [CrossRef]

30. Barnes, E.C.; Jumpathong, J.; Lumyong, S.; Voigt, K.; Hertweck, C. Daldionin, an unprecedented binaphthyl derivative, and diverse polyketide congeners from a fungal orchid endophyte. Chem. Eur. J. 2016, 22, 4551-4555. [CrossRef] 